\section{TINJAUAN FIQH TERHADAP HOMOSEKSUAL}

\section{Syarifuddin, S.Ag, M.A}

\section{Dosen Fakultas sains dan Teknologi UIN Suska Riau}

\section{Abstract}

Sanction of Lawn to deed of homosexual according to syari'at Islam is the same as sexual. Islam always connects it with instinct of seks, because Islam looks into instinct of seles is one of the natural strength which there is in buman being. This instinct of Seks needs channeling having the character of biologis which in form of marriage, because marriage is life demand which is esensial.

In this case, Islam doesnot give indication that instinct of seles is virulent something which causes riot to human being. However, Islam arranges instinct of sekes to run its function as according to mankind. Therefore, Islam is very opposing of a kind of homosexual, which can damage of human being fitrah as God khalifah under the sun

\section{Keywords: Hukum Islam, Homoseksual, sanksi}

\section{PENDAHULUAN}

Hukum Islam adalah bersifat universal yang mengatur semua aspek kehidupan manusia, baik manusia dengan Tuhan maupun hubungan manusia dengan sesama manusia lainnya. Dalam pelaksanaannya hukum Islam senantiasa memperhatikan kemaslahatan manusia, dengan demikian ia memerintahkan setiap pengikutnya menjalankan perintah serta menghentikan larangan-Nya. Hukum Islam akan bertindak tegas para pelaku yang melanggar ketentuan dan peraturan yang telah ditetapkan berdasarkan nash Al-Qur'an dan hadits. Prinsip ini merupakan suatu yang esensial dan faktual dalam menangani masalah kemaslahatan yang terjadi dalam masyarakat Islam. ${ }^{1}$

Hukum Islam pada hakekatnya adalah peraturan Ilahi untuk mengatur tata kehidupan manusia dalam berbagai hal. Sebagai peraturan Ilahi ia akan dapat terealisir dalam kehidupan nyata, bila timbul kesadaran umat Islam untuk mengamalkan semua peraturanperaturan Ilahi tersebut dalam kehidupannya. Hukum Islam ini akan efektif berlaku apabila umat Islam menjadikannya sebagai kebutuhan pokok dalam hidupnya. Terutama dalam melaksanakan setiap perintah dan menghentikan semua larangannya sebagai mana yang digariskan oleh Al-Qur'an dan Hadits. ${ }^{2}$

Suatu keutamaan yang khusus dimiliki oleh hukum Islam, adalah ia tidak boleh diabaikan dalam kehidupan manusia, karena pengabaian itu akan membawa suatu akibat yang amat fatal bagi kehidupan manusia itu sendiri. Untuk itu ia senantiasa harus dilaksanakan setiap saat dalam peradaran waktu, tanpa memandang perobahan kondisi sosial, yang disebabkan perkembangan peradaban manusia. Dengan demikian disaat itu pulalah hukum Islam akan terrealisir secara nyata dalam satu masa. Sehingga tidak akan berjalan semua bentuk peraturan yang dibuat manusia, kecuali peraturanperaturan Ilahi yang tertuang dalam teks Al-Qur'an dan Hadits. ${ }^{3}$

Peraturan Ilahi yang dirumuskan dalam ajaran Islam, sesuai dengan fitrah manusia, dengan maksud Allah menghendaki agar fitrah manusia mempunyai fungsi dan tugas, tidak disia-siakan tanpa mamfaat, seperti yang telah dijelaskan di dalam Al-Qur'an. Firman Allah Swt:

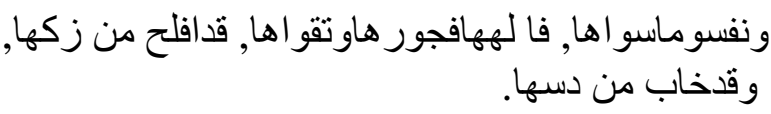

'Lihat Muhammad Saltut, Al-Islam Aqidatun Wa Syari'atun, (Mesir: Darul Qalam, 1986), hlm. 12 dan Lihat hlm. 303.

${ }^{2}$ Lihat Sayyid Quthub, "Hadza Ad-Dien" alih bahasa Suwito Suproyogi, Inilah Dienul Islam, Jakarta: Media Da'wah, 1987), hlm. 1 dan 2.

${ }^{3}$ Ibid., hlm. 3. 
Artinya: "Dan demi satu jïwa yang menciptakannya. Lalu menunjukean kepada jiwa jalan kebaikan dan kejahatan. Sesunggubnya berbahagialah orang yang membersibkan diri. Dan celakalah orang yang menipu Dia" (Asy-Syams 7 -10).

Disamping itu Allah juga menginginkan supaya ajaran Islam dijalankan dengan baik sesuai dengan kemampuan yang mereka miliki, و الذيـن جاهدو افينا لنهـ ينـهـ سبـلنا,

Artinya: "Dan umat yang sungguh-sungguh dan cinta kepada ajaran Kami, pasti kami tunjukekan jalan Kami”" (Al-Ankabut; 69).

Ayat-ayat ini menghendaki agar manusia mempunyai kesadaran mematuhi peraturan peraturan dalam semua aspek kehidupan.

Hukum Islam adalah merupakan suatu sistim hukum yang sangat sesuai dengan manusia, karena pembentukan hukum Islam itu senantiasa memperhatikan kemaslahatan manusia dalam menghadapi berbagai masalah serta tantangan sepanjang kehidupannya. Hal ini disebabkan Islam mengetahui hakekat jiwa manusia beserta dengan kekuatan dan kemampuan yang dimilikinya, dalam membentuk akhlak Islam. Akhlak yang diajarkan Islam bukan hanya berisi tentang larangan dan pembatasan yang bersifat mencegah, tetapi juga terdapat suatu dorongan untuk mengujudkan kepribadian yang bertaqwa kepada Allah.

Suatu tuntutan dari akhlak Islam adalah berusaha menciptakan kebaikan dan memberantas semua bentuk kejahatan, hal ini berdasarkan atas pandangan Islam bahwa fitrah manusia cendrung untuk berbuat baik, sebab manusia diciptakan dari proses alami yang suci, yang mana subtansi jiwanya berasal dari subtansi yang maha sucisubtansi Allah. Akan tetapi dibalik itu terdapat nilai kebebasan dan kemerdekaan dari kehendak hawa nafsu manusia yang ingin melampiaskan seksual yang melanggar ketentuan hukum Islam, yang merupakan penyimpangan biologis diluar fitrah manusia. ${ }^{4}$

Islam mengakui bahwa manusia mempunyai hastrat yang sangat besar untuk melangsungkan hubungan seksual, terutama terhadap lawan jenisnya, maka untuk itu Islam melalui sistim hukum yang berdasarkan Al-Qur'an dan Hadits, mengatur penyaluran kebutuhan biologis melalui perkawinan. Melalui perkawinan inilah fitrah manusia bisa terpelihara dengan baik, sebab perkawinan mengatur hubungan seks antara pria dan wanita dengan ikatan yang syah dalam bentuk monogami dan poligami sesuai dengan ketentuan Al-Qur'an dan Hadits.

Dengan adanya lembaga perkawinan yang disyari'atkan Islam, ini berarti syari'at Islam melarang semua bentuk hubungan seks diluar perkawinan. Sebab hubungan seks diluar perkawinan itu menimbulkan kekacauan hubungan biologis, yang dapat merusak garis keturunan serta menimbulkan berbagai bentuk kejahatan yang membawa manusia kedalam sikap permusuhan dan pembunuhan. Hal ini dapat terjadi lantaran timbulnya kecemburuan, yang disebabkan pertukaran pasangan dalam melakukan hubungan seks diluar perkawinan.

Perkawinan sebagai mana yang dikemukakan, bukan hanya sekedar pemenuhan kebutuhan biologis, bahkan perkawinan merupakan sarana bagi pembinaan pribadi manusia untuk mempertahankan kesucian fitrahnya. Dalam perkawinan diatur hubungan suami isteri, hubungan orang tua dengan anak, kewajiban suami, kewajiban serta hak isteri, kewajiban orang tua terhadap anaknya, dan sebaliknya dengan demikian melalui perkawinan terbentuk keluarga, yang merupakan dasar kehidupan masyarakat. Dari faktor-faktor inilah syari'at Islam memandang perkawinan mempunyai

${ }^{4}$ Yang dimaksud dengan penyimpangan biologis adalah semua bentuk hubungan sek diluar perkawinan, seperti zina, pergundikan, dan hubungan sek lainnya. Lihat Sayyid Sabiq, Fiqh al-Sunnah, Juz’ VI, (Kuait: Dar Al-Bayan, 1968), hlm. 10-11. 
kedudukan yang tinggi dalam kehidupan individu, keluarga dan masyarakat. ${ }^{5}$

Disamping Al-Qur'an meletakkan perkawinan sebagai derajat yang tinggi, Al-Qur'an juga sangat menentang semua bentuk hubungan seksual diluar ketentuan-ketentuan hukum Islam. Karena perkawinan atau nikah mengandung arti larangan menyalurkan potensi-potensi seks dengan cara-cara diluar ajaran agama atau menyimpang. Faktor inilah yang menyebabkan Islam melarang hubungan bebas antara berlainan jenis, serta hubungan sesama jenis yang merangsang nafsu birahi yang tidak dibenarkan oleh ajaran Islam. ${ }^{6}$

Kendatipun Islam telah mengatur hubungan biologis yang halal serta syah, namun penyimpangan-penyimpangan seksual senantiasa selalu terjadi, baik berupa delik perzinaan, lesbian maupun berbentuk homoseksual. Penomena ini terjadi dikarenakan adanya dorongan kebutuhan biologis tanpa terkontrol dengan baik, yang disebabkan kurangnya memahami serta menjalankan ajaran agama yang ia anut. Akibatnya mereka kurang mematuhi larangan-larangan yang terdapat dalam Al-Qur'an dan Hadits, mengenai penyimpangan seks. Sedangkan naluri seks itu sendiri merupakan naluri yang paling kuat dan keras yang selamanya menuntut adanya jalan keluar. Bilamana jalan keluar tidak dapat memuaskannya, maka manusia tersebut mengalami kegoncangan dan kehilangan kontrol untuk mengendalikan nafsu birahinya, dan timbullah hubungan seks diluar ketentuan hukum Islam, seperti Homoseksual (Liwath) yang merupakan pokok pembahasan studi ini.

\section{HOMOSEKS DAN PERKEMBANGANNYA}

1.Homoseks Dalam Fakta Historis

5Ibid., hlm. $18-22$

${ }^{6}$ Perkawinan merupakan sebuah lembaga yang mempertautkan hati, memelihara kemaslahatan dan memadukan cinta kasih antara kedua belah pihak yang berteman hidup.
Homoseks merupakan perbuatan keji dan termasuk dosa besar, dan termasuk salah satu perbuatan yang merusak unsur etika, fitrah, agama dan jiwa manusia. Karena homoseks adalah hubungan biologis antara orang yang sama jenis kelamin, baik sesama pria maupun sesama wanita. Namun istilah homoseks ini dipakai untuk seks antara pria sesama pria, sedangkan seks sesama wanita dinamakan lesbian. ${ }^{7}$

Hubungan biologis semacam homoseks ini dilakukan dengan cara memasukkan zakar kedalam dubur, sedangkan lesbian dilakukan dengan cara melakukan mastrubasi satu sama lain atau dengan cara lainnya untuk mendapat kenikmatan (Orgasme atau Climex Of The Sex Act). Perbuatan homoseks adalah menyimpang dari fitrah manusia karena fitrah manusia menghendaki hubungan biologis secara Hetero Sex, yakni hubungan seksual antara pria dan wanita, melalui akad perkawinan yang syah. Perbuatan homoseks bukan hanya terdapat didalam zaman modern ini, tetapi telah terjadi pada zaman Nabi Luth, seperti yang dinyatakan oleh Al-Qur'an;

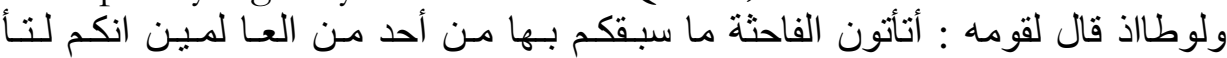

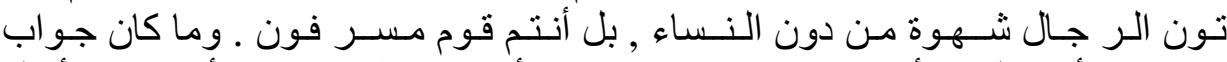

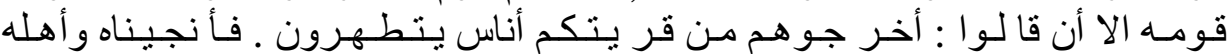

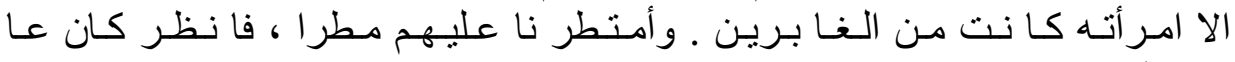

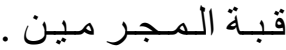

Artinya: "Dan Luth! Tatkala ia berkata kepada kaumnya : mengapa kamu mengerjakan perbuatan kotor itu, yang belum pernah dikerjakan oleh seorangpun didunia ini sebelummu? Sesunggubnya kamu mendatangi laki-laki untuk melepaskan nafsumu kepada mereka, bukan kepada wanita, babkan kamu ini adalah suatu kaum yang melampani batas. Jawab kaumnya tidak lain hanyalah menyatakan "Usirlah mereka (Luth beserta pengikut-pengikutnya) dari desamu ini" sesunggubnya mereka adalah orang-orang yang berpura-pura mensucikan diri.

${ }^{7}$ Sayyid Sabiq, Ibid., hlm. 427. 
Kemudian kami selamatkan dia dan pengikut-pengikutnya kecuali istrinya; dia adalah termasuk orang-orang yang tertinggal (dibinasakan). Dan kami turunkan kepada mereka hujan batu; maka perhatikanlah bagai mana kesudahan orang-orang yang berdosa itu”. (Surat Al-A'raf, Ayat 80, 81, 82, 83, dan 84).

Dalam tafsir Al-Manar dijelaskan, bahwa Nabi Luth diutus Allah untuk memperbaiki aqidah serta akhlak kaumnya, yang berdiam dinegeri Sadum, Amurah, Adma', Sububim dan Bala, dipinggir laut mati. Nabi Luth memilih untuk tinggal dinegeri yang paling besar dari kelima negeri itu, yaitu Sadum. Negeri Sadum sebagai mana diketahui mengalami kehancuran moral, kaum lakilaki lebih bersyahwat memandang sesama jenis dan kurang tertarik dengan kaum wanita sebagai lawan jenisnya untuk berhubungan seksual. ${ }^{8}$

Nabi Luth seketika menyaksikan perbuatan kaumnya yang tidak bermoral itu, lantas menegur dan memperingatkan mereka untuk meninggalkan kebiasaan homoseksual, karena perbuatan itu adalah perbuatan keji. Ia mengajak untuk menyalurkan naluri seks sesuai dengan fitrah manusia melalui perkawinan antara pria dan wanita. Seruan dan ajakan Nabi Luth itu mereka tentang dengan mengusirnya dari kehidupan mereka. Dengan sikap demikian mereka terus mengerjakan perbuatan keji, dan tidak bermaksud untuk meninggalkan kebiasaan homoseksual. ${ }^{9}$

Usaha Nabi Luth untuk menyadarkan kaumnya dari perbuatan-perbuatan keji tidak membawa hasil yang maksimal, karena sikap kaumnya yang ingkar terhadap ajaran yang membawa kepada kebajikan dan kemulyaan. Kesabaran Nabi Luth menghadapi kaumnya, senantiasa mendapat perlindungan dari Allah, seperti yang dinyatakan dalam Al-Qur'an :

${ }^{8}$ Lihat Rasyid Ridha, Tafsir al-Manar, (Kairo: Matba'ah Haja'ri, 1959), hlm. $509-510$.

Ibid., hlm. $511-513$

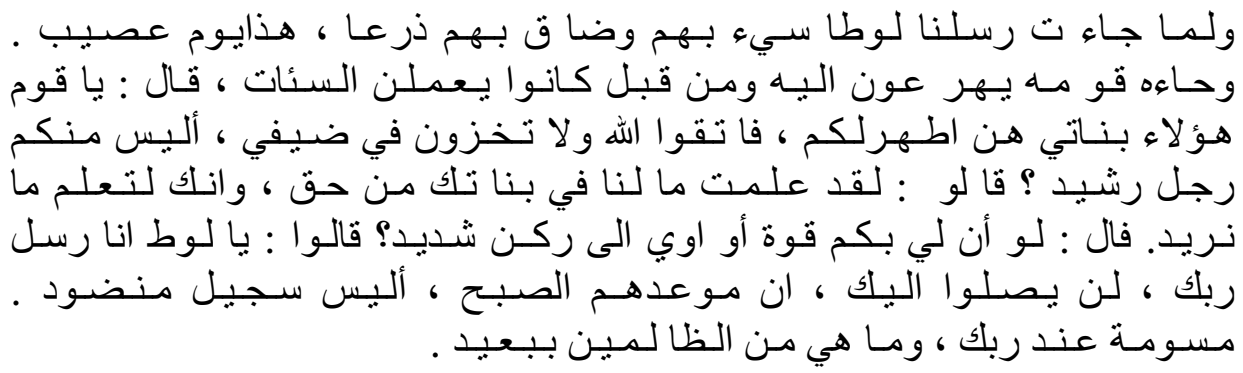

Artinya: "Dan tatkala datang utusan-utusan Kami (para malaikeat) itu kepada Luth, dia merasa susah merasa sempit dadanya karena kedatangan mereka, dan dia berkata: "Ini adalah hari-hari yang sulit". Dan datanglah kaumnya bergegas-gegas. Dan sejak dahulu mereka selalu mengerjakan perbuatan yang keji, Luth berkata; Hai kaumku, inilah putri-putriku, mereka lebih suci darimu, maka bertakwalah kepada Allah dan jangan kamu mencemar namaku terbadap tamuku ini. Tidak adakah diantaramu orang yang berakal ?. mereka menjawab "Sesungguhnya kamu telah tabu bahwa kami tidak mempunyai keinginan terbadap putri-putrimu; dan sesunggubnya kamu tentu mengetahui apa yang sebenarnya yang kami kehendaki. Luth berkata: "Seandainya aku mempunyai kekuatan untuk menolakmu atau kalau aku dapat berlindung kepada keluarga yang kuat, tentu aku lakukan. Para utusan (malaikat) berkata "Hai Luth, sesunggubnya kami adalah utusan-utusan Tubanmu, sekali-kali mereka tidak akan dapat mengganggumu, sebab itu pergilah membawa keluargamu dan pengikut-pengikut kamu di akhir malam dan tinggal kecuali istrimu, Sesunggubnya dia akan ditimpa arab yang menimpa mereka, karena sesungguhnya saat jatubnya azab kepada mereka ialah diwaktu subuh, bukankah subub itu sudah dekat?. Maka tatkala datang azab Kami jadikan negeri kamu Luth itu yang diatas kebawah dan kami bujani mereka dengan batu dari tanah yang terbakar dengan bertubi-tubi, yang diberi tanda oleh Tuhanmu, dan siksaan itu tiadalah jauh dari orang-orang yang ralaim". (Surat Huud, Ayat, 77, 78, 79, 80, 81, dan 82). 
Perbuatan kaum Luth ini telah melampaui batas kemanusiaan, yang telah memutarkan haluan syahwat kearah sesama jenis, dengan mendatangi laki-laki dan tidak berminat untuk mendatangi wanita-wanita sebagai mana yang ditawarkan oleh Luth. Perbuatan semacam ini telah membawa akibat yang sangat fatal, karena dapat merusakkan akal dan jiwa, disamping menimbulkan kehancuran akhlak, yang membawa tindak kejahatan yang menghilangkan ketentraman masyarakat. ${ }^{10}$

Kejahatan yang dilakukan oleh kaum Luth yang bertentangan dengan fitrah dan syari'at itu, mendapat hukuman serta siksaan dari Allah dengan memutar balikkan negeri mereka, sehingga penduduk negeri Sadum termasuk isteri Nabi Luth sendiri terbenam bersamaan dengan terbaliknya perkampungan Sadum. Yang tinggal hanyalah Nabi Luth beserta para pengikutpengikutnya yang sholeh, taat menjalankan perintah Allah dan menjauhkan diri dari homoseks. ${ }^{11}$

\section{Homoseks Dalam Masyarakat Modern}

Kendatipun kaum Luth telah dihancurkan oleh Allah ribuan abad yang lalu, namun perbuatan-perbuatan homoseksual itu tetap saja berjangkit ditengah kehidupan manusia. Ancaman serta siksaan yang amat keras yang ditimpakan kepada kaum Luth sebagai akibat dari homoseksual dan lesbian, tidaklah diperhatikan sebagai tamsil atau pelajaran untuk mencegah homoseksual dan lesbian. Bahkan dunia dewasa ini dilanda revolusi seks, semuanya itu telah melampaui batas dan ketentuan agama.

Menurut George Harvard, dalam bukunya Revolusi Seks, mengungkapkan. Sekarang kita tidak begitu khawatir terhadap bahaya nuklir yang akan mengancam kehidupan manusia di abad modern dewasa ini. Akan tetapi yang kita khawatirkan adalah

${ }^{10}$ Ibid., hlm. 517 - 522

${ }^{11}$ Ibid., serangan-serangan bom seks, yang setiap saat dapat meledak, menghancurkan moral manusia. Pandangan semacam ini juga dilontar oleh Sejarawan Arnol Toynbee yang menyatakan, “ Dominasi seks dewasa ini akan mengakibatkan runtuhnya peradaban manusia". 12

Pernyataan para ahli ini didasarkan atas fakta emperis, yang melihat hubungan seks tidak lagi terbatas antara dua orang suami isteri atau antara dua insan yang berlainan jenis, bahkan sudah melebar kebentuk hubungan seks sesama jenis kelamin, baik berbentuk homoseks maupun lesbian. Faktor inilah yang melatar belakangi James Ruston menulis pada harian New York Times, yang menyatakan bahwa tenaga seks lebih besar bahaya dari tenaga nuklir. Penomena ini dapat dibuktikan dari catatan resmi Dewan Kesehatan Dunia, bahwa terdapat puluhan juta orang melakukan homoseksual, diantara mereka terdapat tiga juta orang di Amerika. ${ }^{13}$

Penyimpangan seksual itu bukan hanya dilakukan oleh orang-orang atais yang menyangkal wujud Allah yang menentang hari berbangkit, tetapi juga dilakukan sebahagian orang beragama, yang meyakini keesaan Tuhan serta meyakini adanya alam akhirat. Problema ini disebabkan peradaban manusia dewasa ini telah mengarah kematerialis, dan mejauh dari agama serta semua nilai spritual, sehingga individu-individu tenggelam dalam kelezatan syahwat semacam perzinaan dan homoseksual. Disamping itu didalam masyarakat kota terdapat berbagai sarana pembangkit api syahwat serta naluri-naluri hewaniah. ${ }^{14}$

Bagi orang-orang yang melakukan penyimpangan seksual, dan menenggelamkan dirinya dalam kelezatan syahwat, akan

${ }^{12}$ Fathi Yakan, "Al-Islam Wa T-Jin”, Penerjemah Syafril Hamim, Islam Dan Seks, (Jakarta: Al-Hidayah, 1989), hlm. 7-8.

${ }^{13}$ Ibid., hlm. 49.

${ }^{14}$ Lihat Murtadha Mutahari, Manusia Dan Agama., (Bandung: Mizan, 1984), hlm. 58 
mengakibatkan pudarnya perasaan agama, bahkan dapat menjauhkannya dari agama, sebagai mana yang dinyatakan oleh AlQur'an, 'Bila hati manusia telah bergelimang dengan dosa, maka dengan sendirinya iman yang berada dalam kalbunya akan memudar, dan tidak akan dapat menerima bidayah Allah. Sesunggubnya Allah tidak akan memberi petunjuknya kepada orang-orang fasik. (Al-Qur'an Surat 63 : Ayat 6).

Berdasarkan ayat diatas semakin jelaslah bahwa bagi orangorang yang berbuat maksiat sulit untuk dilarang, baik dalam bentuk teguran maupun dalam bentuk sanksi hukum. Keadaan ini telah dicoba oleh berbagai negara untuk memberantas peyimpangan seksual, namun usaha ini tidak memberi hasil sebagai mana yang harapkan, bahkan semakin berkembang dalam berbagai masyarakat. Meskipun akibat dari penyimpangan seksual itu tetap saja dilakukan dengan berbagai cara menurut kemauan para pelakunya. ${ }^{15}$

Dampak dari penyimpangan seks semacam homoseksual itu menurut ahli ilmu jiwa adalah tidak ada keinginannya untuk melangsungkan perkawinan. Jika ada diantaranya yang telah kawin, akan menyuruh laki-laki yang disukainya untuk menyetubuhi isterinya sendiri asalkan laki-laki itu bersedia untuk digaulinya secara homoseks. Bahkan ada diantaranya yang lebih buruk moralnya, yaitu bila orang ini telah berusia lanjut tidak sanggup mendatangi, dia sendiri minta didatangi oleh laki-laki lain yang lebih muda, dengan membayar sejumlah uang sebagai imbalan dari mendatanginya. Akibat dari perbuatan ini dirasakan oleh perempuan, dengan tidak merasa puas bersetubuh sama laki-laki, maka timbullah keinginan sesama mereka untuk melakukan hubungan seks sesamanya. ${ }^{16}$

Menurut Dr. Muhammad Rashfi di dalam kitabnya Al-Islam wa al-Thaib, sebagai mana yang dikutib oleh Sayid Sabiq, bahwa

15Ibid., hlm. 59.

${ }^{16}$ Lihat Hamka, Tafsir Al-Az̧ar, (Jakarta: Panjimas, 1979), hlm. 290.
Islam melarang keras homoseks, karena mempunyai dampak yang negatif terhadap kehidupan pribadi dan masyarakat antara lain adalah sebagai berikut:

1. Tidak mempunyai keinginan terhadap wanita, tetapi keinginannya tertuju kepada sesama jenis laki-laki. Jika mereka melangsungkan perkawinan maka isterinya tidak akan mendapatkan kepuasan biologis, karena nafsu birahi suaminya tertumpah seketika melangsungkan homoseks terhadap lakilaki yang didatanginya.

2. Perasaan cinta sesama jenis kelamin membawa kelainan jiwa, dan timbul suatu sikap dan prilaku yang ganjil, yang berlainan dengan sikap laki-laki normal. Sikap pasangan homoseks adakalanya membawa prilaku sebagai orang laki-laki dan adakalanya sebagai pembawaan perempuan.

3. Mengakibatkan rusaknya saraf otak, dan melemahkan daya akal serta menghilangkan kemauan untuk berusaha dan lainnya. ${ }^{17}$

Disamping akibat diatas yang ditimbulkan oleh homoseksual, terdapat pula akibat yang sangat membahayakan bagi kelangsungan hidup seseorang, yakni berjangkitnya penyakit Aids. Penyakit Aids yang menyebar keberbagai penduduk dunia, cukup menggentar orang-orang yang melakukan penyimpangan seks, karena para ahli kedokteran sulit untuk menemukan obat untuk menyebuhkan penderita yang diserang oleh penyakit Aids tersebut, yang membawa penderita kehilangan daya ketahanan tubuh, akibat serangan bakteri yang menyerang pembuluh darah dan kulit tubuh serta alat kelamin. Jumlah korban dari penyakit Aids ini banyak sekali terutama negara-negara Eropa dan Amerika Serikat. Hasil survei di Amerika Serikat pada tahun 1985 ditemui

${ }^{17}$ Lihat Sayyid Sabiq, Fiqh Al-Sunnah, (Libanon: Darul Fikar, 1981), hlm. 361 -365. Pendapat Muhammad Rashfi diatas tetap aktual bila kita melihat masalah homoseks beserta akibat-akibatnya. Bahkan prilaku para pasangan homo itu sendiri telah menyimpang dari fitrahnya sebagai insan, karena mencintai orang yang sama dengan jenis kelaminnya, dan tidak mencintai lawan jenisnya perempuan atau melangsungkan hubungan seks. 
12.000, penderita penyakit Aids, dari jumlah ini terdapat $73 \%$ akibat hubungan Free Sex, terutama homoseks, 17\% akibat penyalah gunaan obat bius norkotika atau sejenisnya, dan 2,5\% akibat tranfusi darah. ${ }^{18}$

Selain penyalit Aids yang terjangkit dewasa ini terdapat pula penyakit kelamin lainnya seperti spilis. Menurut ahli medis Prancis, bahwa setiap tahunnya di Prancis terdapat tiga puluh ribu orang meninggal akibat penyakit spilis, sementara itu di Amerika Serikat terdapat tiga puluh sampai empat puluh ribu orang menderita penyalit spilis. Menurut ahli penyakit ini menular seketika berlangsungnya hubungan seksual semacam zina, homoseks dan lesbian. Kuman spilis akan menular melalui luka kemudian kuman itu membiak dan berkembang. Penyakit in sangat berbahaya, penderitanya bisa menjadi lumpuh karena lemahnya daya tahan tubuh dan membawa kematian. ${ }^{19}$

Disamping bahaya terdapat individu pelaku homoseks, juga membahayakan terhadap masyarakat. Tatkala individu enggan untuk kawin, dan melampias nafsu seksnya secara tidak legal, dengan sendirinya hilanglah sistim kekeluargaan, dan mengakibatkan hilangnya pondasi masyarakat. Sehingga menimbulkan kerapuhan dan kehancuran akhlak, dan terlepas dari ikatan nilai-nilai dan norma-norma agama dan akhirnya membawa kebebasan tampa batas, seperti yang kita saksikan berjuta-juta pemuda-pemudi yang hidup dalam masyarat secara bebas tampa mengindahkan nilai-nilai moral dalam kehidupan nyata. ${ }^{20}$

Dalam hubungan ini Muhammad Quthb mengatakan, "Moral bukanlah merupakan suatu hal yang terpisah dari

${ }^{18}$ Data-data penulis muat dalam tulisan diatas diambil dari kitab Mazfuk Zuhdi, Masail Fiqhiyah, (Jakarta: Karya Unipress, 1988), hlm. 39.

${ }^{19}$ Lihat Fathi Yakan, Al-Islam Wa..., hlm. 47 dan 71.

${ }^{20}$ Homoseks merupakan perbuatan yang merusak akhlak, dan para pelakunya pasti berakhlak jelek, tabiatnya bejat, dan tidak dapat membedakan antara yang baik dengan yang buruk. Lihat Sayyid Sabiq, Fiqh Al..., hlm. 431. kenyataan, dan bukan pula teori-teori yang dipelajari di menara gading, terpisah dari yang lain. moral tidak mempunyai aturanaturan khusus selain aturan kehidupan nyata. Tidak mungkin terdapat kerusakan moral bila kehidupan masyarakat berjalan dengan benar". Ada satu hal yang perlu kita ketahui bahwa, apabila kehidupan rusak, maka moralpun ikut rusak, dan bila moral rusak kehidupanpun ikut rusak. Keduanya merupakan suatu aturan yang bertumpu kepada wujud manusia secara keseluruhan dan fitra yang sempurna. ${ }^{21}$

Untuk menghindari akibat negatif homoseks, memerlukan pembinaan akhlak masyarakat sesuai dengan nilai-nilai dan normanorma agama. Pembentukan akhlak masyarakat merupakan utopia, selama prinsip dan sistim yang berlaku bersifat materialistis yang sangat bertentangan dengan prinsip dan sistim agama. ${ }^{22}$

Hilangnya rasa keagamaan dalam kehidupan manusia, serta tidak adanya pelaksanaan hukum Allah dimuka bumi, dan berkuasanya hukum-hukum dari teori materialisme, adalah merupakan faktor-faktor terjadinya penyimpangan seks. Problema seks, beberapa tahun terakhir ini memperlihatkan kegilaan yang mengerikan, ia adalah hasil dari kondisi, keyakinan, pemikiran dan moral materialis. Melihat keadaan yang demikian pemuka agama serta para ahli medis, berusaha keras menanggulangi dan memecah penyimpangan seks, seperti di Swedia pada bulan April 1964 terdapat 140 orang dokter ahli mengajukan memorandum kepada parlemen, untuk segera mengatasi kekacauan seks, yang mengancam kesehatan dan kestabilan masyarakat. Hal yang sama juga dilakukan di Inggeris tahun 1976, terutama dari kaum wanitanya, yang menuntut agar pemerintah mengembalikan akhlak masyarakat. ${ }^{23}$

${ }^{21}$ Lihat Jahiliyah al-Qarnu 'L-'Isyrin dalam fathi Yakan, Ibid., hlm. 16 17.

${ }^{22}$ Lihat Fathi Yakan, Ibid., hlm. 14.

${ }^{23}$ Lihat Fathi Yakan, Ibid., hlm. 14 
Tuntutan dari pemuka agama serta ahli-ahli medis tersebut mendapat respon dari penguasa, namun pemerintah di negara industri tersebut tidak mampu membendung penyimpangan seks, karena keadaan sudah demikian parah, yang berakal dari pelepasan nilai-nilai serta norma agama dalam semua aspek kehidupan masyarakat.

\section{ISLAM DAN HUKUM HOMOSEKS}

Para ulama fiqh sepakat atas keharaman homoseks menurut ketentuan syari'at. Dan homoseks merupakan suatu yang keji, sebagai mana halnya dengan Jarimah zina, ia termasuk dosa besar, dan merupakan perbuatan yang merusak akhlak serta tidak sesuai dengan fitrah pribadi manusia. Lagi pula ia merupakan musuh manusia yang nyata, yang berlawanan dengan sunnatullah yang alami, karena itulah Allah memandangnya suatu yang keji sama halnya dengan zina, seperti firman Allah : "Karena itulah Allah mengharamkan dan melaknatkan homoseksual. ${ }^{24}$

\section{Pembuktian Terhadap Perbuatan Homoseks}

Meskipun homoseks dinyatakan haram dan merupakan perbuatan terkutuk, namun dalam menjatuhkan hukuman terhadap para pelakukannya memerlukan bukti yang jelas, baik melalui pengakuan dari pelakunya maupun keterangan dari saksi. Dalam hal ini para ulama fiqh berbeda pendapat tentang penentuan jumlah saksi untuk menetapkan jarimah homoseks. Al-Malikiyah, Al-Syafiiyah, dan Hanafiyah, berpendapat bahwa saksi terhadap homoseks sama halnya dengan saksi zina, yaitu terdiri atas empat orang saksi dari laki-laki yang adil, dan tidak terdapat dari salah seorang diantaranya perempuan. Sedangkan Al-Hanafiyah berpendapat bahwa saksi homoseks tidak sama dengan saksi masalah zina, karena kemudharatan yang ditimbulkan oleh homoseks lebih ringan dari

${ }^{24}$ Lihat Abdurrahman Al-Jaziri, Kitab Al-Fiqh 'Ala al-Muzabibul al-Arba'ah, (Bairut Lebanon: Ahya’ al-Tardisu al-Arabi, t.t), hlm. 139. kemudharatan yang ditimbulkan oleh zina, dan jarimahnya lebih kecil dari jarimah zina, serta tidak menimbulkan percampuran keturunan. Karena itu homoseks cukup hanya dua orang saksi saja untuk membuktikannya, dan tidak perlu menghubungkannya dengan zina, kecuali ada dalilnya. Jika tidak diperoleh dalil dari Al-Qur'an dan Hadits, maka ditetapkanlah hukum asal. ${ }^{25}$

\section{Hukuman Homoseks}

Disamping itu para ulama fiqh juga berbeda pendapat tentang hukum homoseks, terutama ukuran-ukuran hukuman yang akan dilaksanakan terhadap para pelakunya, dalam hal ini terdapat tiga pendapat antara lain adalah:

1. Pendapat yang menyatakan bahwa pelakunya harus dibunuh secara mutlak,

2. Pendapat yang menyatakan bahwa pelakunya harus dihadd sebagai mana hadd zina. Jadi bila pelakunya adalah jejaka maka ia harus didera. Jika pelakunya muhshan maka ia harus dihukum rajam,

3. Pendapat yang menyatakan bahwa pelakunya dikenakan hukuman ta'zir. ${ }^{26}$

Pendapat pertama; terdiri dari para sahabat Rasul, Nashir, Qasim Bin Ibrahim, dan Iman Syafi'i (dalam satu pendapat) menyatakan para pelaku homoseks dikenakan hukum bunuh, baik pelaku homoseks itu seorang bikir atau seorang muhshan. Yang menjadi dasar hukum dalam hal ini adalah hadits Rasulullah sebagai berikut :

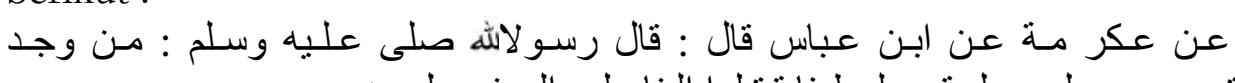

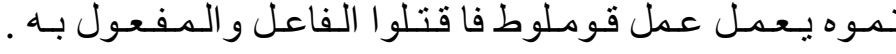

Hadits tersebut dimuat pula dalam kitab Annail, yang dikeluarkan oleh Hakim dan Baihaqi. Kemudian selanjutnya Al-Hafizh

\section{${ }^{25}$ Ibid.,}

${ }^{26}$ Sayyid Sabiq, Fiqh al-.... hlm. 432. 
mengatakan bahwa perawi-perawi hadits tersebut dapat dipercayai, akan tetapi hadits itu masih diperselisihkan kebenarannya. ${ }^{27}$

Al-Malikiyah, Al-Hanabilah, dalam suatu riwayat Al-Syafi'iyah, mereka berpendapat bahwa hadd homoseks adalah rajam dengan batu sampai mati, baik yang melakukannya seorang yang masih bikir atau seorang muhshan. Yang menjadi dasar pendapat mereka ini adalah sabda Rasulullah Saw, yang dilafazhkan sebagai berikut:

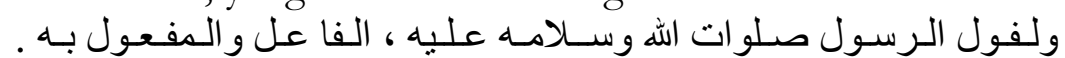

Hadits ini juga telah dikeluarkan oleh al-Baihaqi dari hadits Sa’id Ibn Jabir, dan Mujahid dari Ibn Abas r.a bahwa ia ditanya tentang bikir yang melakukan homoseks, maka ia menjawab bahwa hukumnya adalah rajam, dengan dasar sabda Rasulullah Saw. Sebagai berikut:

$$
\text { فرودنعه أن حده الر جم بكر ا كان ثيبا. }
$$

dalam suatu riwayat, Abu Bakar pernah mengumpulkan para sahabat Rasul untuk membahas persoalan homoseks. Diantara sahabat rasul yang paling keras pendapatnya adalah Ali Ibn Abi Thalib, ia mengatakan "Homoseks adalah, perbuatan dosa yang belum pernah dikerjakan oleh para umat kecuali umat Luth- sebagai mana yang kalian maklumi. Dengan demikian pelaku homoseks harus dibakar dengan api. ${ }^{28}$

Berdasarkan dalil-dalil yang dikemukakan diatas, bahwa hadd yang dikenakan kepada pelaku homoseks adalah hukum bunuh. Akan tetapi para sahabat Rasulullah kelihatannya juga berbeda pendapat dalam menetapkan bagaimana cara membunuh para pelaku homoseks tersebut. Menurut Abu Bakar pelaku homoseks dibunuh dengan pedang, kemudian dibakar. Demikian juga pendapat Ali Ibn Thalib

${ }^{27}$ Lihat Sayyid Sabiq, Ibid., hlm. 433. Haditsnya lihat, Musnad Al-Imamm Ahmad Ibn Hanbal, Jilid II, Al-Maktab Al-Islami, 417.

${ }^{28}$ Sayyid Sabiq, Fiqh al...., hlm. 433. beserta sebahagian besar para sahabat Rasul, seperti Abdillah Ibn Zubair, Hisyam Ibn Abdul Malik dan lainnya. ${ }^{29}$

Sedangkan menurut Umar dan Usman bahwa pelaku homoseks harus dijatuhi benda-benda keras sampai ia mati. Ibn Abbas berpendapat bahwa pelaku homoseks harus dijatuhi hukuman yaitu dijatuhkan dari atas bangunan yang paling tinggi disuatu tempat tertentu. Al-Baghawi meriwayatkan dari Syaby, Zuhri, Malik, Ahmad, dan Ishak, mengatakan bahwa pelaku homoseks harus dirajam. Hukum seperti ini juga dikemukakan oleh Tirmizi dari Malik, Syafi'i Ahmad dan Ishak. ${ }^{30}$

Dasar pemikiran para sahabat tersebut menetapkan hukuman homoseksual adalah dibunuh, atas dasar pandangan bahawa homoseks adalah suatu bentuk yang keji, yang sangat dicela oleh oleh Allah. Sebagai mana Firman Allah dalam Al-Qur'an surat Hud ayat 82 - 83;

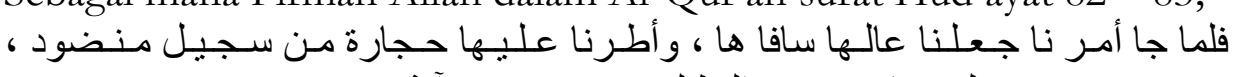

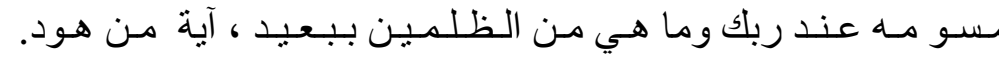

Pendapat kedua, yang menyatakan bahwa pelaku homoseks harus di hadd sebagaimana hadd zina, adalah dipelopori oleh Sa'id Bin Musayyab, Atha' Bin Abi Rabah, Hasan, Qatadah, Nakha'i, Tsauri, Auza'i, Abu Thalib, Imam Yahya dan Imam Syafi'i (dalam suatu pendapat), yang menyatakan bahwa pelaku homoseks yang masih bikir dijatuhi hadd dera serta dibuang. Sedangkan pelaku homoseks itu adalah muhshan maka ia di hadd rajam. Pendapat ini berdasarkan dalil hadits Rasulullah saw;

$$
\text { حكمه حكم الز انى ير جم و المحصن مانة ، }
$$

Dalam riwayat yang lain Ulama Syafi'iyah menyatakan, bahwa hadd yang akan diperlakukan kepada orang yang berbuat homoseks adalah hukuman rajam, baik yang melakukannya seorang bikir atau

${ }^{29}$ Abdurrahman Al-Jaziri, Kitab Al-Figh 'Ala al....., hlm. 141.

${ }^{30}$ Sayyid Sabiq, Fiqh al-...., hlm. 433. 
muhshan. ${ }^{31}$ Akan tetapi pendapat umum dari ulama syafi'iyah adalah hukumnya sama dengan hukum zina, dengan alasan bahwa homoseks sejenis dengan zina. Karena homoseks itu perbuatan memasukkan faraj (penis) kedalam anus lelaki (faraj). Dengan demikian, maka pelaku homoseks sama-sama masuk dibawah keumuman dalil dalam masalah zina baik bikir maupun muhshan. Jadi berlaku ayat yang menyatakan ;

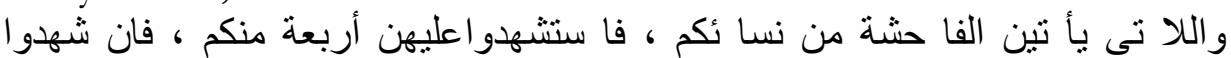

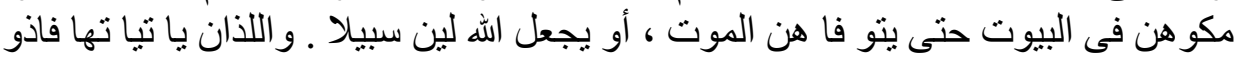

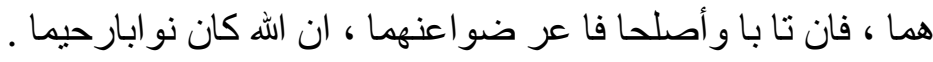

Artinya: "Dan para wanita yang mengerjakan perbuatan keji, hendaklah ada empat orang saksi diantara kamu. Kemudian apabila mereka telah memberi persaksian, maka kurunglah mereka (wanita-wanita itu) dalam rumah sampai mereka menemui ajalnya atau sampai Allab memberi jalan yang lain kepadanya, kemudian jika keduanya bertaubat dan memperbaiki diri, maka biarkanlah mereka, sesunggubnya Allah maba menerima taubat lagi maba penyayang. (An-Nisa', 14, 15 dan 16).

Para ulama fiqh berpendapat bahwa ketentuan yang terdapat dalam surat An-Nisa' merupakan hukuman yang pertama dikenakan terhadap kejahatan zina. Menurut Ar-Razi, yang meriwayatkan dari Muslim Al-Ashfihani, bahwa ayat:

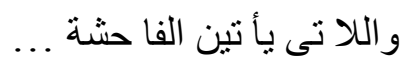

Adalah khusus berkenaan dengan kejahatan sesama wanita (Lesbian). Sedangkan hukumannya seperti yang tersebut dalam ayat, yaitu kurung dalam rumah sampai mati. Akan halnya ayat yang kedua ini :

$$
\text { و اللذان يأتيا نها منكم ... }
$$

Adalah khusus berkenaan dengan kejahatan antara sesama-laki-laki. Hukumnya adalah siksaan dengan perkataan dan perbuatan. ${ }^{32}$

${ }^{31}$ Abdurrahman Al-Jaziri, Kitab Al-Fiqh 'Ala al........, hlm. 141.

${ }^{32}$ Lihat Muhammad Syaltut, Al-Islam Aqidatun Wa....., hlm. 290.
Sedangkan ketentuan hukum tentang masalah zina, yakni hubungan seksual antara pria dan wanita diatur dalam surat An-Nur ayat 2-3, yang berbunyi :

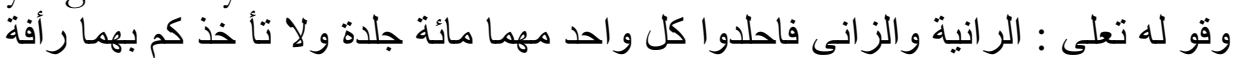

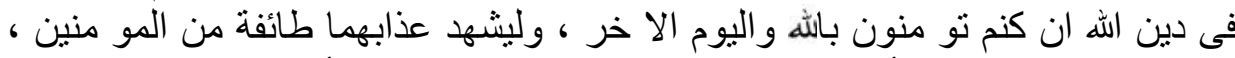

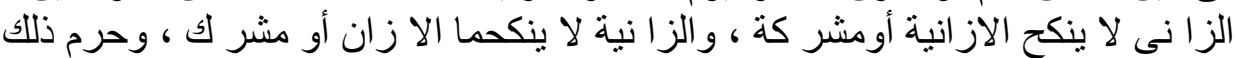

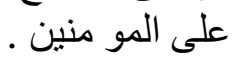

Artinya: "Perempuan yang berzina dan laki-laki yang berzina, maka deralah tiap-tiap seorang dari keduanya seratus kali dera, dan janganlah belas kasiban kepada keduanya mencegah kamu untuk menjalankan agama Allah, jika kamu beriman kepada Allah dan hari akbirat, dan bendaklah (pelaksanaan bukuman disaksikan oleh sekumpulan dari orang-orang yang beriman. Laki-laki yang berzina tidak mengawini melainkan perempuan yang berzina, atau perempuan yang musyrik, dan perempuan yang berzina tidak dikawini melainkan oleh laki-laki yang berzina atau laki-laki yang musyrik, dan yang demikian itu diharamkan atas orang-orang yang mu'min. (An-Nur ayat, 2-3).

Para ulama fiqh memperlakukan ayat dalam surat An-Nur ini kepada orang yang bukan muhshan. Sedangkan mengenai muhshan mereka menetapkan hukumannya rajam, yang berpedoman kepada perbuatan dan sabda Rasul. ${ }^{33}$

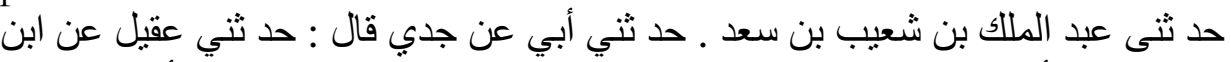

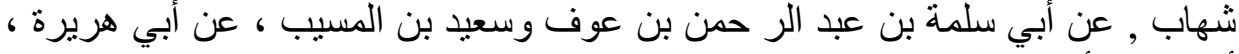

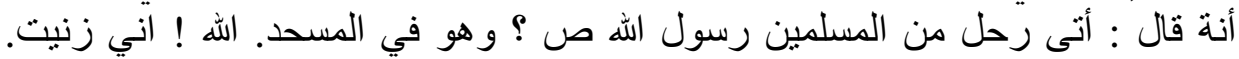

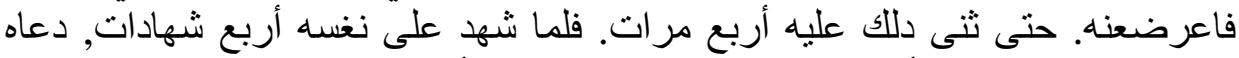
رسول الله ص ؟ فقال, أبك جهون؟ قال : لا. قال : فهل أحصنت ؟ قال: نعم. فقال رسو الله

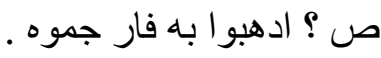

Artinya: "Telah diberitakan kepadaku Abdullah Ibn syu'ib Ibn Lais Ibn Sya'id. Telah diberitakan kepadaku bapakku dari nenekku, ia

${ }^{33}$ Ibid., hlm. 291. 
berkata, telah dikhabarkan kepadaku oleh 'Akil dari Ibn Syahab, dari Abi Salamah Ibn Abdurrabman Ibn Auf dan Sya'id Ibn Al-

Musyaiyab, dari Abi Hurairah bahwa ia berkata, ada seorang lakilaki datang kepada Rasulullah, beliau sedang berada didalam mesjid, laki-laki itu memanggil-manggil Nabi seraya mengatakan, bai Rasulullab, aku telah berbuat rina, tapi aku menyesal. Ucapan ini diulanginya sampai empat kali. Setelah Nabi mendengar pernyataannya yang sudah empat kali diulanginya itu, lalu beliaupun memangilnya, seraya bertanya apakah engkau ini gila? Tidak, Jawab laki-laki itu. Lalu Nabi bertanya lagi, adakah engkau ini orang yang mubshan? Ya, jawabnya. Kemudian Nabi bersabda lagi, Bawalab laki-laki ini dan langsung rajam oleh kamu sekalian (H. R. Bukhari dan Muslim).

Dalam kaitan hadirs ini Ibn Syihab mengatakan, aku ikut melakukan rajam atas laki-laki itu. Dia kami rajam di mushalla, dekat perkeburan dan juga tempat menyembahyangkan mayit, sebelum dikubur. Ketika dikenai lemparan batu pertama, laki-laki itu lari dan kami kejar dan tertangkap, kami teruskan hukuman rajam. ${ }^{34}$ Hadits yang lain juga menyatakan bahwa muhshan dihukum rajam, sebagaimana yang dikemukakan oleh Umar bin Kahatab sebagai berikut :

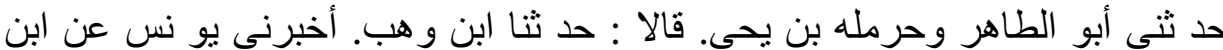

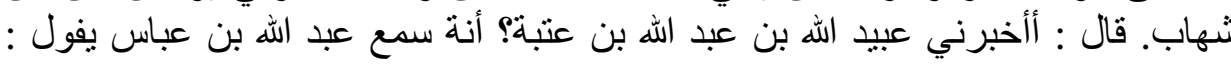

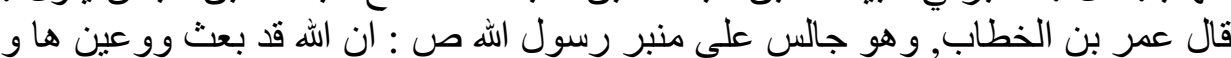

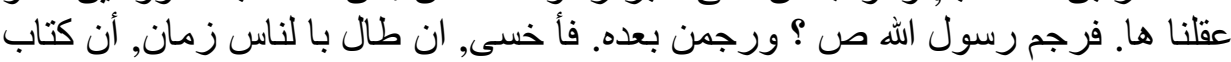
الله حق على من زنى اذا أحصن, من الر جال ور و النساء , اذا قامت البينة , أو كان الحبل أو أو

${ }^{34}$ Sayyid Sabiq, Fiqh al....., hlm. 436.

${ }^{35}$ Syahib Muslim, Musnad Al-Imamm Abmad Ibn Hanbal, Jilid II, Bairut: AlMaktab Al-Islami, tt., hlm. 108.
Artinya: "Abu Al-Thabir dan Harmalah Ibn Yabya telah menceritakan padaku, ia berkata, telah diberitakan kepada kami oleh Ibn Wabab. Telah diberitakan kepadaku Yunus dari Ibn Sbahab. Ia berkata, telah diberitabukan kepadaku oleh Abdullah Ibn Abdullah Ibn 'Utbah, bahwa ia mendengar Abdullab berada di atas mimbar Rasulullah Saw; Sesunggubnya Allab Swt telah mengutuskan Mubammad dengan sebenar-benarnya dan telab pula menurunkan kepadanya sebuah kitab suci, salah satu diantara ayat-ayatnya yang terkandung dalam kitab suci itu terdapat ayat rajam yang telab kita baca bersama dan telah pula kita pabami bersama. Rasulullah sendiri pernah melaksanakan rajam kitapun melaksanakannya. Hal seperti ini suatu kesesatan oleb karena meninggalkean suatu kewajiban yang justru benar-benar diturunkan Tuban. bukuman rajam barus dilaksanakan kepada laki-laki dan perempuan yang melakukan zina mubshan, dengan syarat terdapat bukti-bukti atau dia hamil atau dia sendiri mengakui perbuatannya. Demi Allah seandainya orang tidak menudubku menambah-nambah kitabullah, niscaya aku tuliskan pendapatku ini dalam kitab Al-Qur'an dan aku sejajarkan pula dengan ayat-ayat Al-Qur'an. (H.R. Bukhari, Muslim, Abu Daud, Tirmizi, dan Nasa'i).

Hukum rajam benar adanya, berdasarkan hadits mutawatir yang diakui oleh para ahli hadits dan keterangan Nash Al-Qur'an, sebagai mana yang diceritakan oleh dalam khutbah Umar Bin Khatab diatas, baik diperlakukan kepada muhshan yang berzina maupun muhshan homoseks, karena menurut Ibn Arabi dalam Ahkam AlQur'an, bahwa antara zina dengan homoseks atau liwath itu adalah sama, yakni sama-sama melakukan hubungan seks yang diharamkan oleh syari'at, karena itu hukumnya sama, yaitu muhshan dirajam sampai mati. ${ }^{36}$

${ }^{36}$ Lihat Ibn 'Arabi, Ahkam Al-Qur'an, 'Isya Al-Babi Al-Jalabi wa Ayirkahu. 1968, hlm 1313. 
Pendapat ketiga, yang menyatakan bahwa pelaku homoseks harus diberi sanksi berupa ta'zir. Pendapat ini pertama kali dilapori oleh Abu Hanifah, dalam hal ini ia mengatakan pelaku homoseks dihukum ta'zir, sejenis hukuman yang bertujuan edukatif, dan besar ringannya hukuman ta'zir diserahkan kepada pengadilan (hakim). Hukuman ta'zir dijatuhkan terhadap kejahatan atau pelanggaran yang telah ditentukan macam dan kadar hukum oleh nash Al-Qur'an dan Hadits. ${ }^{37}$

Penetapan hukum secara ta'zir terhadap homoseks oleh Hanafiyah adalah atas dasar pemikirannya, yang menyatakan bahwa homoseks tidak membawa akibat yang lebih mudharat bila dibandingkan dengan perzinaan. Hal ini dapat dilihat bahwa homoseks tidak akan membuahkan keturunan dan tidak pula merusakkan garis keturunan seseorang. Karena itu homoseks tidak dapat dihubungkan dengan zina, dan tidak diperoleh dalil dari Al-Qur'an dan Hadits mengenai ketetapan hukuman homoseks. ${ }^{38}$ Untuk itu masalah ini diserahkan kepada ketetapan hakim secara ta'zir.

Berdasarkan pendapat-pendapat para ulama figh di atas dapatlah dipahami, bahwa pendapat pertama yang menyatakan bagi pelaku homoseks dihukum bunuh merupakan pendapat yang terkuat, karena berdasarkan nash sahih (hadits) yang jelas maknanya; sedangkan pendapat yang kedua yang menyatakan hukuman homoseks sama hukum zina dianggap lemah, karena bertentangan nash yang telah menetapkan hukuman mati dan bukan hukuman ta'zir.

Dalam hubungan ini penulis berpegang pada pendapat yang pertama, sebagai mana yang ditegaskan oleh hadits Nabi, riwayat Khamsah,

$$
\text { منوجد ثموخ يعمل عمل قوم لوط فاقتلو الفا عل و المفعول به . }
$$

${ }^{37}$ Abdul Qadir 'Audah, Al-Tasyri' Al-jinayah Al-Islami Muqaran Bil Qanun AlWadbi, Vol I, Iskandariah; Dar Nasyr Al-Syaqafiyah, 1949, hlm. 185-186.

${ }^{38}$ Abdurrahman Al-Jaziri, Kitab Al-Figh 'Ala al........, hlm. 139.
Barang siapa menemukan orang yang melakukan homoseks seperti yang dilakukan kaum Luth, maka bunuhlah si pelakunya dan yang diperlakukan. Berdasarkan hadits ini pula para sahabat Rasul menetapkan hukuman pelaku homoseks dizamannya, seperti yang dilakukan oleh Abu Bakar dan Ali Bin Abi Thalib. Dengan menerapkan hukuman bunuh ini para pelaku homoseks tidak dapat memindahkan perbuatan keji kepada orang lain, dan orang lain akan merasa takut untuk melakukan homoseks, karena dihadapan matanya terbentuk hukuman bunuh yang mengerikan, yang pada suatu ketika dapat dilaksanakan pada dirinya, bila mengerjakan homoseks.

\section{HIKMAH DARI LARANGAN HOMOSEKS}

Islam menetapkan legislasi dan hukum pada dasarnya adalah bersifat mendidik dan preventif, yang dapat menjamin keselamatan individu dan ketentraman masyarakat. Karena itu sanksi hukum yang ditetapkan oleh Islam merupakan jalan untuk mendidik. Dengan melaksanakan hukuman tersebut masyarakat dapat terpelihara dari berbagai kejahatan dan penyimpangan. Hukum adalah penghalang sebelum terjadinya kejahatan dan pencegahan setelah itu . dengan mengetahui sanksi hukum dari suatu kejahatan dapat menghalangi seseorang untuk bertindak. Terlaksananya hukuman bagi mereka yang melakukan kejahatan semacam homoseks dapat mencegahnya untuk mengulanginya. ${ }^{39}$ Dan akan menimbulkan kesadaran hukum terhadap anggota masyarakat yang lain untuk menghindari perbuatan homoseks dan penyimpangan-penyimpangan seks lainnya.

Hikmah lain yang dapat ditarik dari larangan homoseksual itu adalah mempertahankan lembaga perkawinan. Sebab bila homoseksual tidak diberantas atau dilarang secara syari'at, maka kecendrungan untuk melaksanakan perkawinan tipis sekali, akibatnya akan menghancurkan fitrah manusia sebagai khalifah Allah dimuka bumi ini bahkan melanggar ketentuan sunnatullah dan hukum Allah. Dalam hal ini Allah Swt, maha mengetahui tentang perkembangan

${ }^{39}$ Fathi Yakin, Al-Islam Wa....., hlm. 59. 
biologis manusia, maka itulah Allah mengsyari'atkan adanya lembaga perkawinan untuk menyalurkan kebutuhan biologis.

Dalam Islam, perkawinan merupakan suatu cara yang manusiawi dan terpuji untuk menyalurkan nafsu seks bagi setiap orang, dan tidak menimbulkan kerusakan bagi masyarakat. Bahkan perkawinan itu sebagai basis alami, tempat bertemunya pria dan wanita dalam usaha mencari ketenangan jasmani dan rohani. ${ }^{40}$ Disamping itu perkawinan memberi jalan yang aman pada naluri seks untuk memperoleh keturunan yang baik. Islam juga mengakui bahwa naluri seks merupakan naluri yang paling kuat dan keras selamanya menuntut jalan keluar. Bila jalan keluar tidak ditemui atau memuaskannya, maka manusia itu akan mengalami kegoncangan biologis dan akhirnya akan mengarah keberbagai penyimpangan seks (homoseksual). Karena itu, perkawinan merupakan suatu jalan yang paling baik dan sesuai untuk menyalurkan naluri seks, sebagai mana yang dinyatakan oleh Allah dalam Al-Qur'an surat Ar-Rum ayat 21, sebagai berikut:

ومهن اياتـه أن خاق لكم مسن أنفسكم أزواجا لتسكنوا البها وجعل ينكم مـودة

Artinya: 'Dan diantara tanda-tanda kekuasaan-Nya, ialah Dia menciptakan untuk.mu ister-isteri dari jenismu sendiri, supaya kamu cendrung dan merasa tentram kepadanya; dan dijadikan-Nya diantaramu rasa kasih sayang.

Bila naluri seks tidak disalurkan melalui perkawinan, maka manusia akan mengalami kekacauan. Zina umpamanya akan membawa kekacauan terhadap hubungan nasab, sebab anak yang dilahirkan tidak mempunyai garis keturunan yang jelas dari silsilah bapaknya. Demikian pula halnya dengan homoseksual, akan menghilangkan fitrah manusia dan akan meruntuhkan sistim keluarga dan masyarakat, bahkan akan memutus perkembangan manusia

${ }^{40}$ Ibid., hlm. 28. berikutnya, sebab hubungan seks sesama laki-laki tidak akan membuahkan keturunan.

Selain itu pihak perempuan kehilangan kebutuhan biologis, sebab laki-laki tidak mengadakan hubungan seks dengannya, kesepian semacam ini akan mengakibatkan pula penyimpangan seks dikalangan perempuan. Hal ini akan mendorong mereka untuk mengadakan hubungan seks sesama mereka (lesbian). Dengan cara ini timbul sikap untuk menghindari perkawinan dengan kaum laki-laki, bila hal ini terjadi dalam kehidupan manusia maka semua bentuk peranata sosial akan mengalami kehancuran, dan pada gilirannya manusia akan musnah dari permukaan bumi ini. Lantaran itu wajarlah Allah melarang perbuatan homoseks itu secara keras dan tegas, dengan maksud menyelamatkan kehidupan manusia dari kemusnahannya. Hal ini yang merupakan hakekat larangan homoseks yang digariskan Allah dalam Al-Qur'an dan Hadits.

Hikmah lainnya yang amat besar artinya dari larangan homoseksual itu adalah terpeliharanya akhlak dari kehidupan umat manusia. Hukum Islam sangat mengutamakan kemulyaan akhlak, karena dengan terpeliharanya akhlak manusia dapat menjalankan fitrahnya sesuai dengan sunnatullah. Disamping itu akhlak yang baik membawa ketentraman bagi manusia untuk menjalankan perintah serta menghentikan larangan yang telah disyari'atkan oleh Allah dalam Al-Qur'an dan Hadits.

\section{KESIMPULAN}

Persepsi Islam terhadap fitrah manusia, senantiasa menghubungkannya dengan naluri seks, karena Islam memandang naluri seks adalah salah satu kekuatan yang alami yang terdapat dalam diri manusia. Naluri seks ini memerlukan penyaluran yang bersifat biologis yang berbentuk perkawinan, sebab perkawinan adalah tuntutan hidup yang esensial. Dalam hal ini Islam tidak memberi indikasi bahwa naluri seks adalah sesuatu yang jahat, yang menimbulkan keonaran bagi manusia. Akan tetapi Islam mengatur naluri seks untuk menjalankan fungsinya sesuai dengan fitrahnya 
sebagai insan. Oleh karena itu Islam sangat menentang hubungan seks semacam homoseksual, yang dapat merusak eksistensi fitrah manusia sebagai khalifah Tuhan di bumi.

Menurut Islam, homoseks adalah suatu perbuatan keji, yang dapat merusak akal pikiran serta budi pekerti manusia. Karena itu Islam bersikap tegas dan keras terhadap perbuatan terlarang tersebut. Ketegasan Islam ini dapat dilihat dari nash dan hadits yang menjadi dasar hukum bagi para ulama fiqh dalam menetapkan hukuman homoseksual. Meskipun diantara ulama fiqh terdapat perbedaan pendapat, namun mereka semua sepakat atas keharaman homoseksual. Perbedaan pendapat hanya terjadi tentang masalah sanksi hukum yang dijatuhkan kepada pelaku homoseksual. Perbedaan ini terjadi disebabkan perbedaan sumber hukum yang digunakan oleh masing-masing ulama fiqh, disamping berbedanya cara menafsirka ayat-ayat serta hadits yang menjadi dasar bagi penetapan hukum homoseksual.

Dalam menetapkan hukum homoseks ini para ulama fiqh terbagi menjadi tiga pendapat adalah sebagai berikut:

1. Para pelaku homoseks dihukum bunuh, baik pelakunya seorang bikir maupun seorang muhshan, pendapat ini dipelopori oleh Abu Bakar, Ali Bin Abi Thalib,Nashir, Qasim Bin Ibrahim dan Imam Syafi'i (dalam suatu pendapat) serta beberapa orang ulama fiqh lainnya.

2. para pelaku homoseks dijatuhkan hukuman sebagai mana hukuman zina, jika pelaku homoseks itu seorang bikir maka hukumnya adalah didera serta dibuang dari negerinya. Sedangkan pelaku homoseks yang muhshan yang sudah pernah kawin, dihukum dengan hukuman rajam. Pendapat ini dikemukakan oleh, Sa'id Bin Musayyab, Atha' Bin Abi Rabah, Hasan, Qatadah, Nakha'i, Tsauri, Auza'i. Abu Thalib, Imam Yahya dan Imam Syafi'i (dalam suatu pendapatnya).

3. Pelaku homoseks harus diberi sanksi hukuman berupa ta'zir. Sejenis hukuman yang bertujuan edukatf dan prventif, besar ringannya hukuman ta'zir ditetapkan oleh hakim. Pendapat ini dipelopori oleh, Abu Hanifah beserta beberapa ulama fiqh lainnya. Dalam hal ini Abu Hanifah melandasi pemikiran hukumannya, bahwa homoseksual tidak membawa kemudharatan yang dapat merusak keturunan, dengan demikian cukup dijatuhi hukuman ta'zir bagi pelakunya.

Dari ketiga pendapat diatas yang dinilai terkuat adalah pendapat yang pertama, karena berdasarkan nash sahih, sedangkan pendapat yang kedua dan ketiga di pandang lemah, karena memakai qias dalam menetapkan hukum homoseksual. Disamping bertentangan dengan nash yang menetapkan hukuman bunuh atas pelaku homoseksual.

Bila kita lihat konsep hukum Islam dalam memberi sanksi terhadap perbuatan homoseksual sangat berat, yakni berupa rajam, dera dan dibunuh. Sanksi hukuman semacam ini menurut penulis masih tetap relepan untuk diterapkan dalam masyarakat modern, karena undang-undang atau hukum modern dewasa ini tidak mampu membendung atau mencegah berbagai bentuk penyimpangan seksual. Bahkan penomena penyimpangan seks itu semakin meningkat ditengah-tengah kehidupan manusia. Berbagai penyakit yang diakibatkan dari perbuatan penyimpangan seksual sejenis homoseksual itu, juga tidak menyadarkan para pelakunya untuk menghentikan perbuatan tersebut.

Satu-satunya pencegahan yang mampu mengatasi problema homoseksual beserta jenis lainnya adalah melaksanakan sanksi hukum sesuai dengan hukum Islam. Bila hukum Islam ini dapat diterapkan niscaya perbuatan terkutuk semacam homoseksual itu akan melenyap ditengah kehidupan manusia, terutama dalam masyarakat Islam. Pelaksanaan hukum Islam semacam itu memang mendapat kesulitan untuk diterapkan dalam kehidupan sekarang, karena yang menyadari tentang hikmah hukum Islam itu, hanya sebahagian kecil saja diantara umat Islam, terutama dari kalangan intelektual dan ulama. Bila semua lapisan masyarakat Islam menyadari arti pentingnya hukum Islam, dalam menata kehidupan mereka, maka pelaksanaan hukum Islamdapat diterapkan dalam semua aspek kehidupan, jika hal ini 128 
terjadi sesuai dengan tuntutan Al-Qur'an dan Hadits, maka semua bentuk penyimpangan seksual, termasuk homoseks akan hilang ditengah masyarakat manusia.

\section{DAFTAR BACAAN}

Abdul Qadir 'Audah, Al-Tasyri' Al-jinayah Al-Islami Muqaran Bil Qanun Al-Wadhi, Vol I, Iskandariah; Dar Nasyr AlSyaqafiyah, 1949.

Abdurrahman Al-Jaziri, Kitab Al-Figh 'Ala al-Muzabibul al-Arba'ah, Bairut Lebanon; Ahya' al-Tardisu al-Arabi, t.t),

Arabi Ibn, Abkam Al-Qur'an, 'Isya Al-Babi Al-Jalabi wa Ayirkahu. 1968.

Asyarbaini, Kitab Muqbnil Mubtaj, Mesir; Musthafa Al-Baby AlHalaby, t.t.

Asy-Syaukani, Nailul Authar, Mesir; Idratul Ath-Thabdah AlMunirah, 1944.

Al-Hudhri Muhammad, Ushul al-Fiqh, Bairut; Darul Al-Fikri, 1389 H. 1969 M.

'Ali Al-Sya'yis Muhammad, Tafsir Ayatu Al-Abkam, Bairut: Darul Al-Fikri, t.t.

Fathi Yakan, "Al-Islam Wa T-Jin”, Penerjemah Syafril Halim, Islam Dan Seks, Jakarta; Al-Hidayah, 1989

Hakim Abd, Aspek-aspek Pokok Agama Islam, Alih Bahasa M. Ruslan Syidik, Jakarta; Pustaka Jaya, 1982.
Hamka, Tafsir Al-Az̧har, Jakarta; Panjimas, 1979, hal. 290.

Mazfuk Zuhdi, Masail Fiqhiyah, Jakarta; Karya Unipress, 1988.

Muhammad Saltut, Al-Islam Aqidatun Wa Syari'atun, Mesir; Darul Qalam, 1986.

Muhammad Zakaria Al-Kindhi Chalawi, Muwa Ta’ Malik, Juzu’ 13, Al-Nasyar, t.t.

Murtadha Mutahari, Manusia Dan Agama., Bandung; Mizan, 1984.

Rasyid Ridha, Tafsir al-Manar, Kairo: Matba'ah Haja'ri, 1959.

Sayyid Quthub, "Hadza Ad-Dien" alih bahasa Suwito Suproyogi, Inilah Dienul Islam, Jakarta; Media Da’wah, 1987.

Sayyid Sabiq, Fiqh al-Sunnah, Juz' VI, Kuait; Dar Al-Bayan, 1968. , Figh Al-Sunnah, Libanon; Darul Fikar, 1981.

, Musnad Al-Imamm Ahmad Ibn Hanbal, Jilid II, Bairut: Al-Maktab Al-Islami, tt. 